\title{
Employment guarantee or minimum income? Workfare and welfare in developing countries
}

\author{
Jeremy Seekings \\ University of Cape Town / Yale University \\ Paper for USBIG Conference (February 2006)
}

\begin{abstract}
In many parts of the 'South - i.e. the 'developing' countries of the world-widespread poverty is linked to landlessness and unemployment. Two possible responses to such poverty are employment guarantee (or public works) programmes and cash transfers. In general, low-wage job creation is the preferred option of both elites and citizens, but in South Africa cash transfers through a minimum income programme might, perversely, be more viable politically and effective more broadly in terms of poverty alleviation. This paper examines the dilemmas and choices facing South Africa, which experiences unusual levels of both deagrarianisation and unemployment. The relative viability and efficacy of employment guarantees and cash transfers depends primarily on prevailing wages in the 'market'. In a high-wage economy such as South Africa, the political power of organized labour is generally sufficient to prevent low-wage employment creation in public works programmes. In the South African context - in contrast to low-wage settings such as India or Ethiopia - the extension of public welfare might be more viable than an employment guarantee, although the political obstacles should not be underestimated.
\end{abstract}

\section{Introduction: Programmatic choices and the design of welfare regimes in the global South}

In the developing, low- or middle-income countries of the global 'South', many states play little or no role in the alleviation of poverty. Gough et al. (2004) refer to the 'informal welfare regimes' where poverty alleviation depends on the informal networks of kin or community, and the 'insecurity regimes' in which the state and major players in society actually play a destructive, predatory role (notably in large parts of West and central Africa). But in many other countries in the South, the state has played positive and active roles, such that it makes sense to refer to 'welfare regimes' (as EspingAndersen [1990] and others have done for countries in the North). The policies pursued by states have resulted in three kinds of welfare regime in the South (Seekings, 2005a): agrarian regimes, where the state has actively sought to protect or rebuild an agrarian society in which small-scale agriculture and kin relationships protect many against extreme poverty; corporatist regimes, where access to formal welfare arrangements depends on access to employment, and hence employment-related social or private 
insurance; and redistributive regimes, where the state tackles poverty through cash transfers (i.e. social assistance).

These three types of regime emerged in the early or mid-twentieth century. Most corporatist regimes date from the early twentieth century, when workers in formal employment began to secure social insurance against the risks of unemployment and poor health and in preparation for retirement. Because the beneficiaries of such regimes were the formal sector workers with earnings above the median and the costs of social insurance could be passed onto the poor through either tax-financed subsidies or higher prices (at least in closed economies), these corporatist regimes were generally highly inegalitarian, redistributing from the poor to the better off. Faced with challenges of poverty in mid-century, many states moved towards agrarian regimes or (in exceptional cases) introduced social assistance. Land reform and other pro-peasant policies underpinned agrarian regimes in much of Asia and Africa. Social assistance was limited to South Africa, parts of the British Caribbean, and Mauritius.

These Southern welfare regimes were as dependent as their northern counterparts on the maintenance of full - or nearly full - employment. In the North, different kinds of welfare regimes required appropriate labour market policies to contain unemployment (Esping-Andersen, 1990; Castles and Mitchell, 1993). In the South, the efficacy of agrarian regimes depended on the capacity of the agrarian economy to absorb labour, whilst the efficacy of corporatist regimes depended on a large and growing formal sector employment in towns. Both types of regime were linked to clear developmental projects, and depended on the success of 'development'. Even the redistributive regimes assumed full employment: social assistance was provided to adults who were unable to work because of poor health or disability or who were too old to work, and to poor adults with children, but no such assistance was provided to unemployed adults in good health. This reflected in part the fact that, when the redistributive welfare regimes were designed in mid-century, unemployment was low; elites worried instead about labour shortages. Rising unemployment therefore posed major challenges to all of these welfare regimes.

In the late twentieth century, many agrarian societies have experienced marked 'deagrarianisation' (Bryceson and Jamal, 1997), landlessness in rural areas and unemployment in both urban and rural areas. Poverty in these societies can no longer be easily tackled through 'developing' peasant agriculture or the 'modern', formal sector. In the long-run, sustained economic growth is clearly required to expand employment - and with it the possibility that most of the population could be covered by contributory insurance schemes, such that they provide for the risk of sickness or unemployment and for old age through contributions to insurance or savings funds whilst they are working. But, in the short- and perhaps medium-term, states need new poverty-mitigating programmes to cover those poor who have never worked long enough in formal employment and thus are not covered by contributory welfare schemes. In this, states face a basic choice between generating employment, primarily through public works programmes or an employment guarantee, and expanding social assistance to cover the unemployed poor, i.e. a choice between 'workfare' and 'welfare'. 
This paper examines aspects of this choice. It does not discuss the normative or theoretical aspects of the debate around workfare and welfare, between guaranteed employment or minimum (or basic) income. It concentrates rather on a counter-intuitive paradox: In some of the societies in which the need for one or other programme is most pressing, there appears to be a tension between the preference for job creation, among both elites and citizens in general, and the political environment, which impedes or prevents a sustainable and effective job creation programme. This paradox is rooted in the co-existence of high wages and high unemployment in some economies. In countries like South Africa, unemployment is very high in part because high wages result in a restricted demand for unskilled labour. But, if wages on public job creation programmes are linked to existing 'market' wages, then the programmes are unsustainable. Markets are socially constructed, and the practices and policies underpinning high wages are strongly defended by vested interests. In this paper I argue that there are political obstacles to the introduction of significant non-cyclical public works programmes or employment guarantees in countries where labour market policies underpin high wages. In these circumstances, the expansion of social assistance might be more viable, even if benefits are set at a very low level and there is a general preference in principle for job creation.

This paper focuses on the South African case. South Africa is in important respects an unusual Southern case-study, but it serves to illuminate general themes and issues. South Africa experienced deagrarianisation unusually early and fully, as apartheid completed a process of undermining agricultural livelihoods and agrarian society. This was the primary reason for South Africa's exceptional introduction of a range of social assistance programmes, notably in the 1940s. In the later apartheid period, state policies resulted in very high unemployment, exposing the loose weave of the social safety net (Seekings and Nattrass, 2005). In the post-apartheid period, i.e. since the country's first democratic elections in 1994, there have been calls for both public works programmes and the expansion of welfare through some kind of basic income grant or minimum income scheme. But there has been curiously little research on the relative merits, constraints and sustainability of these alternatives, nor does it seem that the comparative literature on employment guarantee or public works programmes has informed thinking about the choice facing South Africa.

\section{Experiences with employment guarantees and social assistance in the South}

In the South, tax-financed programmes to reduce poverty have generally fallen into two categories. First, and more widely, public works programmes or employment guarantee schemes have been introduced to provide income to the otherwise unemployed. Most such programmes have been in response to emergencies, but some have been sustained across long periods of time. Secondly, and more rarely, cash transfers have been provided to the deserving poor through social assistance programmes. The 'deserving' poor have invariably been defined in terms of an inability to work, thus including the 
elderly (at least, those without kin who can or are supporting them), children in poor families, or (exceptionally) the sick or disabled.

Public works programmes or employment guarantees - i.e. workfare - have generally been introduced in response to a crisis of unemployment and poverty, whether the crisis is due to a macroeconomic shock (such as a sudden structural adjustment) or agroclimactic shock (such as drought). Just as workfare programmes were introduced across much of Europe and the USA during the Depression years of the early 1930s, so similar programmes were introduced in (for example) Chile in 1987, South Korea in response to the financial crisis of 1997-98, northeast Brazil in response to drought in 1998, and Argentina in response to recession in 1997 (when unemployment reached 18 percent).

Most of these schemes were temporary. In Brazil, the Northeast Work Front Programme ran for two years (1998-2000), with employment peaking at almost 1.2 million workers at the end of 1998 (Rocha, 2001). But, if the emergency persisted, then programmes could become longer lasting. Argentina's Trabajar programme was introduced in 1997, employing 400,000 people for, on average, five months each. The programme reached approximately one-fifth of the target population of unemployed poor (Subbarao, 2001: 12-13). When the crisis deepened in 2001-02, raising suddenly the proportion of the population living below the poverty line by 20 percentage points, the programme was replaced by a new and expanded Plan Jefes y Jefas, which provided cash for work for 2 million households. The new programme provided cash to unemployed household heads with dependent children or disabled adults. Participants were supposed to work for 20 hours per week on socially useful projects (Galasso and Ravallion, 2004). Botswana introduced a cash-for-work programme in 1992-93, providing 7 million person-days of employment (in a country with a tiny population) (Subbarao, 2001).

Some programmes became permanent responses to poverty. The most famous employment guarantee programme in the South was initiated during a severe drought in the early 1970s in the Indian state of Maharashtra. Maharashtra's growing population reached 80 million in the early 1990s (i.e. approximately double that of South Africa). The Maharashtra Employment Guarantee Scheme (EGS) provided opportunities for unskilled, manual labour on small-scale, labour-intensive rural infrastructural projects. Any adult aged 18 or older in rural areas was guaranteed productive employment (although in practice this goal was not realized). Work has to be provided close to the applicant's home, but the applicant has no choice in the kind of work or precise location. Until the mid-1980s wages were below the official minimum wage, but a 1985 court ruling required wages to rise to the minimum. Between the mid-1970s and late 1980s, the MEGS provided between 100 and 200 million person-days of employment per year, which corresponds to an average of between 5 and 10 days of employment per year for every member of the rural labour-force in Maharashtra and a lot more than this per actual participant. Although the EGS operated year-round, the demand for emergency employment was seasonal, peaking markedly during the dry summer months. A series of studies showed that the EGS targeted the poor and reduced poverty, even when account is 
taken of earnings forgone by participants in the EGS (Ravallion, 1991; Hirway and Terhal, 1994).

The Maharashtra EGS paved the way for a national employment guarantee scheme for landless workers in 1983, with the objective of guaranteeing 100 days of work per year to rural, landless households. The employment generated under this national programme peaked in the late 1980s at about 300 million person-days per year (Hirway and Terhal, 1994: 96). A second national employment programme provided slightly more persondays per year. In 1989 these two national programmes were combined into the Jawahar Rozgar Yojana (JRY), which Hirway and Terhar describe as 'perhaps the single largest employment programme in the world today' (1994: 94). The JRY came to provide about 800 million person-days of work per year, or an average of between 15 and 30 days of work per participant per year. Like the Maharashtra EGS, much of this work was seasonal (Subbarao, 2001). Other sub-national rural public works programmes existed in other states, including Karnataka and West Bengal, generally because of a recognition that the national programmes were inadequate (ibid: chapters 7 and 8).

At the end of 2004, an Employment Guarantee Act was tabled in the Indian Parliament. The Act 'guarantees' at least one hundred days of low-wage employment on public works programmes to one member of every poor household in India. If rolled out nationally, the gross cost is estimated at between US\$6 and 9 billion, or between 1 and 1.6 percent of GDP. But the plan would replace many existing schemes, so that the net cost would be much lower, and it would also be rolled out in stages. ${ }^{1}$

Bangladesh's Food for Work Programme (FFWP), also introduced in the early 1970s, similarly grew to provide approximately 100 million person-days of employment by the late 1980s. Studies concluded that it, too, was well targeted, and reduced poverty significantly (Ravallion, 1991).

In Africa, such public works programmes are less common. Drought-ravaged Ethiopia is an exception. There, the official policy on food aid has been that no able-bodied adult should receive food aid without working on a road-building or other infrastructural public works programme. Only those who are unable to work are eligible for free food aid. The food-for-work and free food programmes are the only publicly-provided safety net in Ethiopia. Between 1999 and 2003, the Ethiopian FFWP employed an average of 1.4 million people per year (Quisimbing and Yohannes, 2005).

Most of these programmes have proved effective in addressing poverty. Not all money spent on these programmes reaches the poor. Administrative costs, leakages to the nonpoor (through poor targeting) and forgone earnings (as some participants might give up other opportunities for employment in the programme) all reduce the direct benefit to the poor. Taking these into account, Ravallion (1991) estimates that the direct income gain to the poor is about 30 to 40 percent of the total government expenditure on the Maharashtra EGS and Bangladesh FFWP. There may also be indirect benefits to the poor from the resulting infrastructure or other outputs, and even from upward pressure on

\footnotetext{
${ }^{1}$ The Economist, 1 Jan 2005, pp.45-6.
} 
the market wage for unskilled labour. In Argentina, the Jefes programme was less well targeted than its Trabajar predecessor, but even here 40 percent of participants came from the poorest income quintile and 90 percent came from the poorest three quintiles. Galasso and Ravallion (2004) found that the Jefes programme was better targeted than other social programmes in Argentina. The unemployment rate was reduced by approximately 2.5 percentage points (but the effect on poverty was larger, as the participation rate rose by about the same amount, as women with dependents who had not been in the labour force joined the programme).

If Maharashtra is the role-model for enduring employment guarantee schemes, South Africa is the model for ambitious social assistance. In no other country in the South does social assistance cover such a wide range of circumstances, reach so many of its citizens or cost so much in relation to GDP. Social assistance programmes are generally limited to conditional cash transfers to the elderly, through old-age pensions that are meanstested and typically depend also on the absence or failure of close kin to support the elderly. More recently, Brazil and Mexico (through what are now the Bolsa Familia and Oportunidades programmes respectively) have led the way in conditional cash transfers to low-income families, where grants are means-tested and conditional on children attending school and/or health care clinics. South Africa provides old-age pensions, with minimal conditions, child support grants to low-income parents and disability grants to the sick or disabled (which has become very important in the context of AIDS). No less than one in five South Africans receive a social assistance grant. The cost is, unsurprisingly, high. Across the South, only Brazil, Mexico and South Africa spend more than 1 percent of GDP on social assistance. Brazil and Mexico spend just over 1 percent (World Bank, 2005) ${ }^{2}$. South Africa spends about 3 percent. $^{3}$

South Africa's social assistance dates from the 1920s, but crucially was extended to African people in the 1940s, albeit with racially discriminatory benefit levels (Seekings, 2000, 2005b). It survived the early decades of apartheid, and in the last years of apartheid became a very generous system because the National Party was pushed to remove racial discrimination in benefits by raising the benefits for black people up towards the benefits previously enjoyed by white people. The result was that, the years after the end of apartheid, the old-age pension and disability grants stand at about US\$100 per month - which was more than the minimum wage set for domestic and farm workers across much of the country. Child support grants are less generous, at about US\$30 per month.

Prior to the 1980s, the only developing countries with significant social assistance programmes were South Africa and some smaller British colonies (Mauritius, parts of the Caribbean and Hong Kong) (Seekings, 2005a). Since the 1980s, however, social assistance programmes have proliferated (Seekings, 2005c). The World Bank has become an enthusiastic supporter of conditional cash transfers to low income families with children, such as the Bolsa Familia and Oportunidades programmes in Brazil and

\footnotetext{
${ }^{2}$ I think that this figure for Brazil excludes the costs of subsidizing the rural pension, so underestimates expenditure as a percentage of GDP.

${ }^{3}$ Financial Mail, 23 Sept 2005, pp.30-31.
} 
Mexico (World Bank, 2005). ${ }^{4}$ In Brazil, the Bolsa Familia programme now (in mid2005) makes payments of up to about US $\$ 40$ per month to 7.5 million poor families, comprising 30 million poor people. Some states top up the benefits. In the north-eastern state of Ceara, for example, families receive up to a total of about $\$ 52$ per month. ${ }^{5}$ In Mexico, Oportunidades reached more than 4 million families (and 21 million people) by 2003. The programme is well-targeted on the poor, with more than one-third of spending going to households in the bottom income decile and three-quarters going to households in the poorest three income deciles (World Bank, 2004: 129-32). Means-tested, noncontributory old-age pensions have been introduced in a wide range of countries. Taiwan and South Korea introduced means-tested old-age pensions. Hong Kong extended its existing pension programme, paying generous benefits to half a million elderly people. In South Asia, means-tested old-age pensions were greatly extended in the 1990s, although they continue to reach a small proportion of the elderly. In India, over 2 million elderly people receive non-contributory pensions. In each of India, Nepal, Bangladesh and Sir Lanka, the benefits are low (US\$2 per month in Nepal) and eligibility strictly limited (including by age), but the strict eligibility makes it likely that the schemes will be expanded in future. In Brazil, largely non-contributory old-age pensions were expanded in the 1990s, and are now paid to about 5 million elderly people.

The first wave of social assistance programmes, in South Africa and elsewhere in the middle of the twentieth century, were introduced from above, in response to crises of poverty that were attributed to irreversible deagrarianisation. Most of these reforms were introduced in open economies, where employers could not pass on the costs of higher wages or social insurance to consumers and thus supported tax-financed social assistance. Most of these economies were also experiencing labour shortages, which rendered public works programmes inappropriate. The problem was low wages, not unemployment. The second wave, since the $1980 \mathrm{~s}$, has been driven by population growth and deagrarianisation, which have resulted in rapid increases in the numbers of poor people in towns or otherwise detached from the land. Globalisation might have accentuated the vulnerability of many groups to poverty. Trade liberalisation also eroded the ease with which employers could pass on the costs of their social security contributions to the consumers. At the same time, fiscal pressures compelled states to reassess their subsidisation of social insurance schemes, especially in Latin America. Most importantly of all, democratisation strengthened the non-unionised poor. Political parties began to use promises of pro-poor welfare reform as a platform to build electoral support. Elections politicised welfare provision. The collapse of protectionist models of development and the shift to more open economies might, perversely, have made it easier to consider tax-funded welfare reforms rather than contribution-funded ones.

Most of the recent social assistance initiatives are focused on particular categories of deserving poor: the elderly, low-income families with children or (exceptionally) the sick or disabled. There are no social assistance programmes aimed at unemployed, ablebodied adults of working age (although of course many such people benefit indirectly by grants given for other, more deserving members of their households). Public works

\footnotetext{
${ }^{4}$ See also The Economist, September $17^{\text {th }} 2005$, leader, p.13.

${ }^{5}$ The Economist, September $17^{\text {th }} 2005$, p.53.
} 
programmes represent the more common policy response to poverty in this group. But the introduction of a basic income grant would change this. In South Africa, in 2002, a government-appointed Committee of Inquiry into a Comprehensive System of Social Security (the Taylor Committee) proposed the introduction of a basic income grant, subject to some provisos. The proposed basic income grant would be set at a low level approximately US\$15-20 per person per month - which is less than one-fifth of the value of the old-age pension, but it would be universal (South Africa, 2002; see also Seekings, 2003). And in 2004, Brazil's President Lula signed a law to introduce a basic income grant (renda basica), in stages - although this law is more of a general statement of intent than an explicit commitment to implementation. There are also lobbies for basic income grants in Namibia and Argentina. In the twenty-first century, developing countries face a real choice in addressing unemployment-linked poverty between public works programmes and radical reform of the welfare system. The following sections of this paper explore this choice with reference to South Africa.

\section{The Challenge: Unemployment and poor health in a post-agrarian society}

The end of the twentieth century saw an extraordinary and widespread process of deagrarianisation spread across many 'developing' countries. In societies that had long been based on peasant or other forms of agriculture, there grew huge new populations of people cut off from the agricultural livelihoods of the countryside and of the social arrangements that were rooted in them. South Africa was, in important respects, at the front of this trend, thanks to the brutal policies of the apartheid state. For largely political reasons, the apartheid state completed the deagrarianisation of South African society in the 1960s and 1970s by removing large numbers of African families off white-owned commercial farms into the 'native reserves' (or 'bantustans'), causing such overpopulation in them that agricultural production largely collapsed there also. By the end of apartheid, smallholder or peasant agriculture accounted for a miniscule proportion of national output, and was even of limited importance to most rural poor (Seekings and Nattrass, 2005).

In South Africa, most income comes from the labour market. The informal sector, repressed under apartheid, remains small, at least relative to the informal sector in much of Latin American. And the bulk of informal sector activity is 'survivalist', meaning that it involves very low incomes that allow someone to survive but not to prosper. In this context, the opportunity to earn a living means, essentially, the opportunity to find a job.

Unfortunately for many South Africans, the labour market provides many fewer opportunities to work than there are work-seekers. In 1994, the unemployment rate stood at about 30 percent of the labour force. It rose over the following decade, passing 40 percent of a (larger) labour force in 2001 (Nattrass, 2000, 2003; Altman, 2003). Unemployment rose despite economic growth. This is because growth was, at least until recently, 'jobless', in that growth converted into higher incomes for the already employed rather than any expansion of employment. Recent data suggest, however, that there has 
been some growth in employment, although at a much lower rate than the increase in the labour force (so that both employment levels and the unemployment rate have risen). Bhorat and Cassim (2004) argue that the increase in employment means that South Africa experienced 'poor employment growth' rather than 'jobless growth'. Casale et al. (2005) show that some of this employment growth is the product of changes in measurement. The rest comprises primarily growth in survivalist informal sector employment, not formal sector employment. Overall, it is clear, recent economic growth has not been significantly more pro-poor than in preceding decades.

Given both the level and trend in unemployment, it is unsurprising that the South African government has queried the unemployment statistics. First, it tried to adopt a Eurocentric definition of unemployment as the official definition. The 'strict' or 'narrow' definition included only active job-seekers, which might be appropriate in Europe or North America but is very inappropriate in Southern Africa where few people get jobs through the recognized activities, instead relying on friends and family to inform them of opportunities - because of both the absence of job opportunities and the fact that most employers themselves fill vacancies by word of mouth, making 'active' job search a futile exercise. This definitional sleight of hand, reminiscent of Thatcherite Britain, reduces the unemployment problem by about ten percentage points. Secondly, ministers and the president himself have queried the accuracy of the data. South Africans themselves do not share their leaders' confusion. Every opinion poll conducted over the ten years since the end of apartheid finds that unemployment or job creation is identified as the most important problem facing the country and government.

Poverty is rooted, primarily, in unemployment. As Leibbrandt et al. point out, 'access to wage income is central to determining which households are able to avoid poverty and even the depth to which poor households sink below the poverty line' (2001: 34). In poor households, fewer adults are available for work (i.e. participation rates are low), and of these adults, few are employed (i.e. unemployment rates are high). In the poorest income decile, nine out of ten households have nobody in employment; in the second poorest decile, three out of four household have nobody in employment. In contrast, in the seventh income decile there are more households with two or more members in employment than there are household with none. And, in the ninth and tenth income deciles - i.e. the richest 20 percent of households - over half of households have two or more members in employment, and negligible numbers of households have none.

Some poor households are supported by non-resident kin, who remit money (generally from wages) regularly or irregularly. In the past, the apartheid-regulated system of migrant labour meant that many households in 'rural' areas were supported by remittances sent by migrant workers on the mines, farms or in urban employment. The end of apartheid has eroded this form of private redistribution. The end of influx control', i.e. restrictions on urban residence, made it easier for migrant workers to settle in town. Whilst many urban residents do maintain some links with rural areas, and some intend to return to rural areas at some point in the future, fewer households are split now in the ways that were common throughout the twentieth century. And, although longitudinal evidence is scarce, it appears that remittances have declined. 
Surveys provide not only data on the incidence and correlates of poverty, but can also be used to give poverty a human face. Consider the following real examples of poor households drawn from the first countrywide survey of incomes and expenditures, conducted in 1993. ${ }^{6}$ Mrs B, who lived in Limpopo Province, was a classic example of a woman dependent on occasional remittances sent by her husband, who was a migrant worker in the industrial heartland of Gauteng. Mrs B was 32 years old in 1993, and had already been pregnant five times, although only three children were born alive. Her husband worked in Gauteng and sent home meagre sums every few months. This was Mrs B's only income. She had no land. Mrs B wanted a job, but didn't even look because (she said) there were none. (She was thus 'unemployed' under the expanded definition but not the narrow definition). Mrs B and her children lived in a 2-roomed cement-block house, with a corrugated iron roof and a mud floor. They had electricity and an electric stove, but could not afford to use it all of the time - so they also cooked with wood (and used candles for lighting). They had no toilet, and collected water from a public tap about quarter of a mile away.

Mr and Mrs G also lived in Limpopo Province. Together with two sons, one daughter-inlaw and her young daughter, they stayed in a plastered brickwork house with an iron roof and two thatch-roofed huts. They had a pit latrine, but no tap or electricity. Mrs G collected water from a borehole twice daily, each trip taking one hour. Three times a week Mr and Mrs G spent five hours collecting wood. They had a radio. Mr G was 67 years-old, and received an old-age pension. This was the family's only income: Mrs G was still too young to receive a pension. Together with her daughter-in-law, who dropped out of standard 8 at school because she was pregnant, Mrs G looked after the small child. Mrs G's older son was unemployed, and did not look for work because there were no jobs. The younger son was still at school. Like many young South Africans, staying in school might have been in part a response to the fact that the alternative is unemployment. High school enrolment rates thus hide even higher unemployment.

There are some 'working poor'. Wages in the agricultural, construction and domestic sectors are generally low. Twenty-eight years-old Ms K lived in North-West Province, with her two younger sisters, and one of her sister's children. Ms K herself was still in school, studying for matric. She had a child, living elsewhere with a relative. Her two sisters had both dropped out of school because, one of them said, it was too expensive. One worked as a cleaner in the local municipal offices; the other sister was unemployed, and was not even looking for work because there just weren't any jobs. They lived in a 2-room, cement block house with an asbestos roof, with a flush toilet inside and a tap in the yard but without electricity.

Poverty has many faces, but these were typical of South Africa at the end of apartheid: households, often comprising three generations (or 'split-generation' households comprising grand-parents and grand-children), with very few members in employment, reliant instead on government welfare (especially the old-age pension) or intermittent remittances from kin elsewhere. Unemployment was widespread, and was

\footnotetext{
${ }^{6}$ These examples are drawn from a larger set in Chapter 6 of Seekings and Nattrass (2005).
} 
underestimated in official figures given that so many younger adults (including the 28 year-old Ms K) remain at school much longer than they would have done in a tighter labour market.

Since the end of apartheid, poverty has taken on another prominent face, as the HIV/AIDS pandemic has swept through Southern Africa. As death rates have risen, especially among younger women, life expectancy has plummeted. In 2001, one in five South Africans between the ages of 15 and 49 were estimated to be HIV-positive; this corresponds to almost five million people. An estimated one third of a million adults and children died of AIDS during 2001. Poverty contributes to HIV/AIDS, primarily because malnutrition and chronic parasitic infection increase vulnerability to HIV. But HIV/AIDS in turn contributes to poverty, as individuals are unable to work and households spend money and time on caring for the sick (Nattrass, 2002). AIDS also strikes at the heart of the relationship between the respective responsibilities of the family, the market and the state. Agencies such as UNAIDS point to the rapidly rising numbers of AIDS orphans, and suggest that 'the extended family and the willing community can never fully cope with the numbers ${ }^{7}$. In this view, the historical division between family and state is breaking down, as the former cannot cope with new demands and pressures (but see Bray, 2003).

Poverty would be much deeper in South Africa were it not for the country's exceptional public welfare system. Social assistance provides an impressive, but incomplete, safety net. The elderly and disabled, and their dependents, are the main beneficiaries. Both are supposedly means-tested, but it seems that the administration of the means test serves only to exclude the rich, not middle-income claimants. Access to pensions alone serves to raise many households out of extreme poverty - the bottom two deciles - and into mild poverty or even above the poverty line. The expansion of coverage of child support grants since the late 1990s has helped many poor households (including, it is likely, Mrs B's household above). The welfare system is also very efficient: administrative costs are low, and most expenditures are well targeted on the poor. But the net is incomplete. Crucially, there is almost no direct coverage for working-age unemployed adults.

The exception to this is the disability grant, which is paid to people who are unable to work. As the HIV/AIDS pandemic has escalated, so more and more AIDS-sick people have claimed disability grants, such that the number of disability grants paid out has risen from about 600,000 in 2000 to over one million in 2003. Many poor households are dependent on the disability grant received by an AIDS-sick member of the household. This has some good effects, for example eroding the stigma attached to HIV/AIDS. But it also generates incentives for poor people to be classified as AIDS-sick - i.e. to be in stages 3 or 4 of AIDS - and thereby become eligible for the disability grant. Most alarmingly, it perhaps provides disincentives for AIDS-sick people to go onto antiretroviral drug treatment programmes that would restore their health - for some period of time - but perhaps render them ineligible for a disability grant. Sick households might be faced with the dilemma of choosing between the improved health of one household member and the loss of the household's main source of income, on the one hand, or

\footnotetext{
${ }^{7}$ Sunday Independent, 12 Jan 2003.
} 
continued poor health for the individual and financial security for the household, on the other (Nattrass, 2006).

\section{The pro-poor promise and uncertain practice of post-apartheid policy}

In much of the developing world, democratization at the end of the twentieth century has advanced hopes that pro-poor policies would be advanced. Indeed, in many settings, competition for the votes of the poor has spurred political parties to introduce pro-poor welfare and other policies. In South Africa, where political discrimination went hand-inhand with very high levels of inequality, there were high expectations of democratization. In the first democratic elections, in April 1994, the African National Congress (ANC) led by Nelson Mandela campaigned under the slogan "A Better Life for All", with its "Reconstruction and Development Programme" (RDP) as its election manifesto. The RDP, which had been drafted in close consultation with the ANC's allies in the trade unions and other movements in civil society, set out boldly the ANC's ambitions. 'Attacking poverty and deprivation' would be 'the first priority' of the democratic government (ANC, 1994: 4). This would entail meeting 'the basic needs of people jobs, land, housing, water, electricity, telecommunications, transport, a clean and healthy environment, nutrition, health care and social welfare' (ibid: 7). Specific promises included the redistribution of 'a substantial amount of land' to the landless; 'over one million houses' would be built; 2.5 million homes would be electrified; and clean water, sanitation, affordable health care and telecommunications would be made available 'to all' (ibid: 8).

The RDP spelt out the four pillars of the strategy for meeting basic needs:

- Creating opportunities for all South Africans to develop to their full potential;

- Boosting production and household income through job creation, productivity and efficiency, improving conditions of employment, and creating opportunities for all to sustain themselves through productive activity;

- Improving living conditions through better access to basic physical and social services, health care, and education and training for urban and rural communities;

- Establishing a social security system and other safety nets to protect the poor, the disabled, the elderly and other vulnerable groups (ibid: 15-16).

Poverty would be addressed thus through both improved opportunities to work and earn a living and direct state support, including through the social security system. The RDP even referred to the 'rights' to 'work opportunities' as well as 'income security' (ibid: 52). Although the RDP was vague in terms of how the social security system would be strengthened, it did include a clear and strong commitment to job creation through public works programmes. Indeed, the emphasis would appear to be more on job creation than on welfare:

Although a much stronger welfare system is needed to support the vulnerable, the old, the disabled and the sick who currently live in poverty, a system of "handouts" for the unemployed should be avoided. All South Africans should have the opportunity to participate in the life of the country. (ibid: 18) 
Social welfare should be 'developmental', in implicit contrast to a 'handout'-based system.

The vision of the RDP was to some extent carried over into the Bill of Rights, that was incorporated as Chapter 2 of South Africa's new constitution. The Bill of Rights even specified that everyone had the right, 'if they are unable to support themselves or their dependents, [to] appropriate social assistance'. (This, like most other social rights in the constitution, is qualified by a clause requiring the state to 'take reasonable legislative and other measures, within its available resources, to achieve the progressive realization of these rights'). But the Bill of Rights was silent about any right to opportunities to work. check

The one area of labour market policy in which the post-apartheid state was quick to reform was the legislative framework governing conditions of employment. A new Labour Relations Act and the 1997 Basic Conditions of Employment Act a strengthened the existing systems of collective bargaining in union-organized sectors and minimum wage-setting in unorganized sectors. Since the mid-1990s, trade unions have using their powers to negotiate steadily rising real wages, despite rising unemployment outside of the workplace. Statutory minimum wages have been introduced in agriculture and domestic work.

The post-apartheid state was much slower to enact labour market reforms intended to promote employment, reduce unemployment and alleviate poverty (see Streak and van der Westhuizen, 2004). This was not due to any lack of debate around this. The decade after 1994 saw repeated examination and discussion of both labour market and welfare policy. A Presidential Labour Market Commission reported in 1996. In 1998, a Presidential Jobs Summit was held, bringing together business and labour in tripartite discussions. In 2000, the government appointed a Committee of Inquiry into a Comprehensive System of Social Security for South Africa, which reported in 2002. The ANC considered a range of anti-poverty programmes at its 'Policy Conference' in 2002. It acknowledged that 'the fight against unemployment is our central challenge', but warned that 'there are no magic solutions or quick fixes' and 'fighting unemployment will be a long haul'. Public works programmes were described as 'useful short-term strategies but [they] are not by themselves a long-term solution' (quoted in McCord, 2004: 7). In mid-2003, another 'summit' was held, this time on 'Growth and Development'. But this talk has led to little in the way of concrete action with respect to either public works programmes or radical welfare reform. As of 2005, therefore, there has been little progress towards either guaranteed employment or guaranteed minimum income. Indeed, there has been little reform of any sort in either direction.

During the 1990s and early 2000s a growing number of business and independent economists pointed to the negative effects of labour market policy on job creation, especially at the unskilled end of the labour market. Labour market policy has negative effects in two major ways. First, industrial relations procedures result in very high costs to employers of dismissing labour. By one estimate, it costs business 1 percent of GDP to dismiss workers each year, and three times the number of work-days are lost through 
dismissal procedures than through work stoppages. Some of the labour lawyers responsible for drafting the relevant labour legislation have spoken out against the gap between what they intended and what has ensued. ${ }^{8}$ Secondly, wages are negotiated in centralized, sector-based Bargaining Councils, which are dominated by the large, more capital-intensive employers together with the trade unions who have a common interest in setting wages at high levels to eliminate competition from small, less capitalised and less organized employers. These are certainly not the only reasons why there is not more demand for unskilled labour - other reasons include the costs of tax and other regulations ${ }^{9}-$ but they are certainly contributory factors in the rise in unemployment among less skilled workers.

The government itself has slowly shifted toward accepting the need for labour market policy reforms to promote employment growth. In 1999, the Minister of Labour introduced very minor changes to the regulations affecting small businesses employing less than ten workers. Most recently, in mid-2005, ANC leaders finally declared their intention of tackling the 'holy cow' of labour market policy. A discussion document, calling for the relaxation of some labour market regulations (ANC, 2005), was tabled at the ANC's major mid-term conference - its National General Council - in July 2005. The paper was written, at the request of the ANC's top leadership, by Jabu Moleketi, the deputy-minister for Trade and Finance. Moleketi argued that South Africa's postapartheid labour market system has reduced industrial disputes, but resulted at the same time in real (i.e. above-inflation) wage increases and job losses. Moleketi proposed excluding small employers from some regulatory requirements and from the sectoral wage deals negotiated between large employers and unions. The proposals explicitly provided for some kind of dual labour market, but called for discussion of the criteria governing such duality.

At every stage, the reform of labour market policy has been strongly opposed by the ANC's powerful allies, the Congress of South African Trade Unions (COSATU) and the South African Communist Party (SACP), both of which operate politically as factions within the ANC. Prior to the 2005 conference, Moleketi had told the press that:

COSATU is on the defensive. It does not want to do anything that will worsen its situation of shrinking membership. But it is not going to solve its situation by being narrow and short-termist. It needs to grow by including the outsiders rather than just protecting the insiders. ${ }^{10}$

Moleketi underestimated COSATU and the SACP. They saw the proposals as 'an attack on existing worker rights', lobbied strongly against them at the conference, and secured a final resolution that left labour market reform off the immediate agenda. Reformers were allowed to save face with a resolution that called for further research to be conducted on the effects of policy on job creation. ${ }^{11}$

\footnotetext{
${ }^{8}$ Financial Mail, 18 February 2005, pp.34-35; 4 March 2005, p.26.

${ }^{9}$ Financial Mail, 24 June 2005, p.44.

${ }^{10}$ Financial Mail, 27 May 2005, pp.22-24.

${ }^{11}$ Financial Mail, 1 July 2005, pp.18-20.
} 
In the absence of any major reforms of labour market policy, the economic growth path has remained resolutely anti-poor. Unions and the government have emphasized the role of public works programmes in addressing unemployment-based poverty. The 1994 RDP referred ambitiously to public works programmes (PWPs). A succession of programmes - the National PWP, the Community-Based PWP and the Special PWP - seemed welldesigned, but none of them was ever fully implemented. McCord calculates that job creation under the Community-Based PWP peaked at about 4 million workdays per year, which corresponded to a fraction of 1 percent of the workdays required to eliminate unemployment (McCord, 2003: 12). By comparison, the Maharasthtra EGS created approximately 100 million workdays per year, i.e. twenty-five times as many workdays in a state with a population only double South Africa's.

At the 2002 Growth and Development Summit there was widespread support for expanding public works programmes, although different parties in the summit had different ambitions for this expansion. The trade unions proposed an ambitious set of publicly-funded public works and community service programmes that would employ 500000 young people with 'allowances' of about R800 (about US\$125 per month). Excluding administration costs, this would cost only R5 billion (i.e. just under US\$1 billion).

In late 2004, the government launched a new 'Expanded' Public Works Programme (EPWP). It was explicitly seen as a 'short to medium-term strategy', providing job 'opportunities' in the interim period before economic growth raised the demand for labour and solved the unemployment problem. The design of the EPWP seems to have been informed by proposals set out in the World Bank's 2001 World Development Report. But, as McCord points out, the World Bank proposals were for problems of cyclical unemployment, not for problems of structural and chronic unemployment. The EPWP has two major features. First, government funding is directed at switching from capital- to labour-intensive production, especially in the construction sector. About 200,000 short-term job 'opportunities' would be created per year, building roads and other infrastructure. Given that these job opportunities were typically of short duration, this would make a small dent on the overall problem of unemployment. Secondly, very small numbers of unemployed people would receive training. As the state is unable to deliver the training programmes that it has already funded, it is unlikely that this new training programme will have much effect. ${ }^{12}$

Welfare reform has attracted more attention than public works programmes. Since 1994, the shape of South Africa's social assistance system has not changed, but coverage and expenditures have grown as more people have claimed and received disability and child grants. But a basic income grant ('BIG') would entail a very radical reform. In South Africa, unusually, a basic income grant is imaginable precisely because the country already has a wide-reaching system of social assistance. South Africans take for granted that the state provides regular and, for the most part, generous financial assistance to specific categories of 'deserving poor'. More importantly, the basic income grant has

\footnotetext{
${ }^{12}$ This paragraph is based on a presentation by Anna McCord in the Centre for Social Science Research at the University of Cape Town (September 2005).
} 
powerful champions among non-government organizations, especially church-based groups and trade unions, organized into a 'BIG Coalition'.

The ANC-led government and the ANC as a party have been less than enthusiastic about a basic income grant, preferring public works programmes. Commenting on the Taylor Committee Report, the government said that it had a rather different 'philosophy' and was opposed to 'hand-outs' to people who were neither disabled nor sick. ${ }^{13}$ Government officials worry about a 'culture of entitlement'. Referring to the 'dignity of work', they say they prefer 'massive' public works programmes. ... Most recently, in mid-2005, the Minister of Finance and National Treasury have taken to bemoaning South Africa's move towards a 'welfare state'....

Both 'massive' public works programmes and a basic income grant remain on the agenda. What do citizens think of these alternative strategies for poverty alleviation? How do they compare in terms of political viability?

\section{The social construction of desert and the political construction of market wages}

A right to work is probably more widely recognized than a right to income. A right to work was included in the Universal Declaration of Human Rights, other international conventions and (reportedly) in the constitutions of at least thirty countries (of which a majority are in the South); most of these thirty constitutions require the state to guarantee the right to employment (Hirway and Terhal, 1994: 40-2). Although the right to work is little more than a statement of intent, in that full employment is one of the government's goals, the priority attached to work probably reflects also a widespread emphasis in public opinion. The right to work is not simply or even primarily a right to an income, i.e. to earnings from employment. It is also a right to inclusion in societies in which work is considered to have intrinsic value. This is surely why workfare is widely more popular than welfare, excepting for those specific categories of deserving poor who are unable to work on grounds of age or disability.

There appears to be curiously little data on public opinion on the relative merits of workfare and welfare, even for countries in the North. There is some evidence on public attitudes to workfare, i.e. of public attitudes to an obligation to work in return for public assistance. In a study of seven European countries, Fridberg and Ploug (2000) found general support for the idea that the right to financial support whilst unemployed comes with some obligations. They found overwhelming support for an obligation on the unemployed to accept training, but more mixed views on the obligation to work. In all seven countries, majorities agreed that 'the unemployed should not be allowed to turn down a job if it is located within an acceptable distance of the place where they live', but in several countries majorities also thought that the unemployed should be able to turn down employment if it did not match their qualifications or experience. Dutch citizens

\footnotetext{
${ }^{13}$ Sunday Times, 28 July 2002.
} 
support strong conditionality for young people - i.e. they are obliged to take work if it is available - but also that work might entail unpaid, socially useful work. Some people (such as single mothers) might be exempted from such a requirement (Van Oorschot, 2004). In general, citizens in many countries - ranging from the USA to the social democracies of Scandinavia and (arguably) the Netherlands - believe that there needs to be tigher controls over access to 'welfare', and that there is an important but not universal obligation to look for and take work. But, at the same time, citizens in these countries also believe that the state should be doing more to help the poor. It is far from clear how this combination of attitudes converts into views on the merits of an employment versus an income guarantee.

There is unsurprisingly much less evidence on what people in the South think about the importance of work to desert. We do have some evidence from Cape Town on what people in this one city think about some aspects of desert, but we do not know how typical these findings are of public opinion in any other parts of the South. This evidence from Cape Town comes two surveys, the first conducted in 2003 with a small but representative sample of adults, the second in 2005 with a larger, representative sample of adults (see Seekings et al., 2003, 2005).

There is overwhelming support in Cape Town for assistance to the categories of poor people generally considered as 'deserving', i.e. the elderly and disabled. Asked if the value of the old-age pension should be increased, eight times as many respondents agree than disagree. This support is general across racial groups and classes. The unemployed are also considered deserving in some sense. The statement 'the government should help the unemployed' elicits the same pattern of responses. In 2005, we presented respondents with versions of a vignette describing a potentially deserving subject of working age, and then asked respondents whether the government should provide financial assistance to this person. When the subject was described as sick or disabled, there was overwhelming support for the provision of assistance. If the subject was a woman who had been abandoned by her husband, and either had dependent children or could not find work, then there was strong support for financial assistance. There was also strong support for subjects who were women looking after sick and elderly parents. But support dropped to about 50 percent for subjects described as simply unable to find work or retrenched when their employer closed. And there was only low support for the provision of financial assistance to subjects who were described as not wanting work or who were said to have lost their jobs because they had been caught stealing or had been late for work because of a drinking problem! In short, whilst there is strong support for the deserving poor, it is easy to sketch scenarios in which people consider certain poor people to be undeserving. Faced with the bald statement that 'the government should provide everyone with a guaranteed basic income', only twice as many people agree than disagree, with a bare majority agreeing. As soon as caveats are added - for example, the need for tax increases to finance this - then it is very likely that support for a basic income grant for all would drop dramatically. ${ }^{14}$

\footnotetext{
${ }^{14}$ We did not add this caveat to the statement about the basic income grant, but we did add it to the statement about increasing the old-age pension. Support for increasing the old-age pension dropped from
} 
Public works programmes have the added advantage of producing potentially useful outputs, for example new or better maintained roads in rural areas. This is reportedly one reason why the rich in Maharashtra accept the Maharashtra EGS (Ravallion, 1991: 157). There is no data on whether this is a factor in the South African case.

The ways in which desert is understood by citizens is probably of less importance than the ways in which wages are determined, given the importance of wage-setting for the viability of public works programmes. Ravallion (1999) and Subbarao (2001), in their reviews of workfare programmes in developing countries, emphasise the importance of setting wages appropriately. The first element in a good (i.e. pro-poor) workfare programme, writes Ravallion, that 'the wage rate should be no higher than the market wage for unskilled manual labour in agriculture or in the informal sector during a normal year in the setting in which the program is introduced' (42). Ideally, Subbarao (2001) suggests, the wage should be just below the market wage (see also Hirway and Terhal, 1994). The wage rate is the primary mechanism by which the programme can be targeted on the poor. If the wage rate is set too high, non-poor (and possibly already-employed) people are attracted to the programme, and it is also harder to reach broadly across any given target population within a fixed budget. Ravallion himself notes that organized labour is likely to resist low wages, except perhaps for an emergency programme (1999: 43).

It will therefore be more difficult to introduce effective and pro-poor public works programmes in economies which have high wages, especially if there are high statutory minimum wages, and where trade unions representing formal sector workers are strong. The Maharashtra EGS was effective for so long in large part because these conditions did not exist in Maharashtra. Even in Maharashtra, however, optimally pro-poor wagesetting became difficult in the mid-1980s. First, a court ruled that the EGS had to pay the official minimum wage. Then, in 1988, the statutory minimum wage was doubled, requiring that the EGS wage was also doubled. The result was that many fewer persondays of employment were generated, there was job rationing on the programme, and the programme was less targeted on the poor. It also meant that employment could no longer be guaranteed in practice (Subbarao, 2001).

Countries like Brazil, Chile and Argentina provide difficult environments for pro-poor public works programmes because they have strong trade unions and statutory minimum wages that are higher than the prevailing market wage in agriculture or the informal sector. Successful programmes in these countries have been able to set low wages in large part because public opinion has supported this as an emergency measure. In Chile, in 1987, programme wages were set at about 70 percent of the minimum wage. In Argentina, the Trabajar programme paid a low wage under the guise that it was not a wage at all but rather 'economic assistance' (and was therefore exempt from minimum wage legislation). After public debate, the programme wage was actually reduced to improve pro-poor targeting (Subbarao, 2001: 8). The subsequent Jefes programme paid

an aggregate 84 percent to 54 percent when we added '... even if it means that people like you have to pay higher taxes'. 
wages equivalent to about one half of mean household income per capita (Galasso and Ravallion, 2004). In South Korea, the programme wage was set at slightly below the market wage for unskilled labour; when market wages fell, the programme wage was reduced also (Subbarao, 2001: 9). The Northeast Work Front Programme in Brazil paid benefits below the minimum wage, of about R80 (US\$45) per month (Rocha, 2001).

Probems with wage-setting are a major reason why, in countries like Brazil, it has proved difficult to sustain public works programmes. In Brazil, municipal and state governments run many small-scale public works programmes but have to pay wages above the official minimum wage and provide also the benefits associated with formal employment. The consequence is that these programmes make little or no difference to poverty. The major programme in Rio de Janeiro city (the Favela Limpa programme) employed just 2000 workers cleaning slums (Rocha, 2001: 12-14). In 1999, the federal government designed a national Programa Piloto de Trabalho Solidario. Monthly wages would be about US $\$ 35-50$, i.e. about one half of the mimimum wage, so as to make the work attractive only to the target population of the very poor and to enable also the funds to be spread widely across many beneficiaries. The programme was never implemented. Rocha (2001) reports that setting the wage below the minimum wage would have been of questionable legality and 'would certainly have triggered resistance at the political and trade union levels'. The most difficult environments in which to introduce pro-poor public works programmes are the post-Communist economies of Eastern Europe and Central Asia, where there are immense political obstacles to setting low wages (Subbarao, 2001).

In post-apartheid South Africa, remarkably little attention is paid to the issue of wages in discussions of public works programmes. The 'chief operations officer' in the national Department of Public Works drew up a list of the lessons to be learnt from public works programmes elsewhere in the world, and omitted any mention of appropriate wagesetting (Phillips, 2004: 5-6) - ignoring completely the authoritative reviews by Ravallion and Subbarao! Indeed, he barely mentions wages at all. The reason for this is buried earlier in the text: Wages and other aspects of employment in public works programmes are governed by an agreement negotiated with the trade unions and gazetted in 2002 as a Code of Practice for Special Public Works Programmes. The Code of Practice allows for minimal relaxation of standard conditions of employment on condition that there is a training component and the duration of employment is limited. The relaxation of the conditions of employment allow for task-based payment and wage-setting in terms of the local going rate for unskilled labour (ibid: 3 ).

The power of organized labour was reflected in the 'prolonged' negotiations leading to the Code of Practice.

... the [trade] union movement was anxious to prevent the emergences of a large body of 'second class' public works employees for whom labour protection was waived, with reduced benefits and wages. The emergence of such a group of workers would contribute to the development of a two-tier labour market, potentially undermining labour protection more generally in South Africa. (McCord, 2004: 11) 
The result, McCord suggests, was 'the creation of temporary employment programmes, similar to those which elsewhere have been a response to temporary labour market disruption or cyclical unemployment' (ibid). McCord is clearly correct in distinguishing the Extended PWP in South Africa from long-lasting programmes like the Maharashtra EGS, but even she underestimates the differences between the South African scheme and temporary schemes such as Trabajar in Argentina. In South Africa, trade unions secured wages that were substantially higher, in relation to the incomes of the poor, than in Argentina and elsewhere.

The Code of Practice provides for wages paid on public works programmes to be slightly lower than the minimum wage paid in the relevant sector and area. For example, on one road-building programme in the poor, rural Limpopo Province, wages were set at R30 per task, which generally converted into R30 (less than US\$5) for a five-hour day (but could be more than this, with some workers earning as much as R1000 or US\$160 per month). But sometimes wages were set at the local minimum wage. For example, on a roadmaintenance programme in rural areas of the KwaZulu-Natal Province, wages were set at the local minimum wage in the construction industry (approximately R42 per day) (McCord, 2004: 15-16). In practice, however, the few full-time jobs in these rural areas pay much less than the official minima wages. In the relevant areas of Limpopo and KwaZulu-Natal, full-time employment as domestic workers or cane cutters on sugar estates reportedly paid between R200 and R300 per month, i.e. R10 to R15 per day. Given that wages on public works programmes are generally for part-time work, they are often higher per hour than for a wide range of employment in rural areas. ${ }^{15}$ Employment on public works programmes - even if part-time only - also pays considerably more than the value of subsistence agricultural production or the earnings derived from informal sector work by households engaged in these (ibid: 35). The Code of Practice therefore required wages on public works programmes that were substantially higher than actual earnings in the area. The result, as McCord notes (ibid: 23), is that the public works programmes attract many more than the poorest, including people who already have lowwage employment or are already engaged in other kinds of work (ibid: 39, 43-4).

Wages of about R35 per day (meaning a five-hour day) would correspond to a monthly wage of about R700 (US\$100) per month (if workers are employed part-time every day). In rural areas, this is a very attractive wage. In urban areas, it is less attractive, largely because of the greater availability of employment at or above minimum wages. In urban areas, wages paid on public works programmes are thus below wages in formal or even casual employment, but above the earnings of most participants in the informal sector.

But what is a 'market wage' in a context in which unskilled wages are pulled upwards by labour policy, including the collective bargaining framework and, in sectors not covered by collective bargaining, statutory minimum wages? 'Markets' are constructed, and as Castles (1985) argued powerfully for the Australian case, labour market policies that empower organized labour in collective bargaining serve to have distributive consequences arguably as profound as redistribution through social policy. There is no

\footnotetext{
${ }^{15}$ The 5-hour day was adopted because productivity in the sixth, seventh and eighth hours of work per day was so low (McCord and van Seventer, 2004).
} 
thorough work on the construction of unskilled 'market' wages in South Africa, making it difficult to assess the relative importance of collective bargaining institutions, minimum wage-setting, the practices of trade unions, the practices of employers, and the attitudes and behaviour of the unskilled themselves. What is clear is that, as we saw above, important officials within the post-apartheid state have come to believe that there are institutional reasons why unskilled wages are high and the demand for unskilled labour is so weak. In this view, public policies have pushed up the 'market' wage for unskilled labour.

One way of assessing the 'market wage' is to examine the supply of labour, i.e. the demand for work among the unemployed. Three surveys in Cape Town provide some evidence on reservation wages, i.e. the minimum wages that people are prepared to accept for employment, in a metropolitan area. Each asked a version of the question 'what is the absolute lowest take-home wage that you would accept?'. A survey in 2002 among adolescents found that, among African and coloured adolescents who had left school without passing the grade 12 ('matric') school-leaving examination, were aged between eighteen and twenty-two years, were looking for or wanted work, and were not currently working, the modal reported reservation wage was R50 per day and the median reported reservation wage was R60 per day. ${ }^{16}$ An earlier, 2000, survey in working-class areas of Cape Town found very similar reservation wages among the unemployed adults (see Nattrass and Walker, 2005). Respondents give lower reservation wages if the question is framed differently. In 2004, for example, Cape Town adolescents were asked the following: 'If a government public works programme came to the area (...) offering R33 a day, would you take a few days work if you were unemployed at the time?' Almost one half of our young respondents said they would. More than one half of the currently unemployed respondents aged between eighteen and twenty-four said they would. ${ }^{17}$

Unfortunately, there does not seem to be any survey data on whether unemployed people would accept work for less than the wages offered by public works programmes. What we do know is that there are many people 'working' in the informal sector, mostly selling (or 'hawking') goods on the street, whose net earnings are way below these sums. It is likely that reservation wages are much lower in rural than in urban areas, not least because there are many more households in rural areas with no regular source of income, making it difficult for the rural unemployed to pass up opportunities of low-wage employment in the expectation of getting better-paid employment later.

These data on reservation wages in Cape Town and the experience of public works programmes in rural areas suggest that there would be a demand for employment at wages below the minimum negotiated by trade unions and accepted under the 2002 Code of Practice. Setting public works programme wages at a relatively high level means inevitably that the benefits of employment are spread less widely and that they will be less targeted on the unemployed and very poor. In a high-wage, highly unionized

\footnotetext{
${ }^{16}$ Data from first wave of Cape Area Panel Study (see further Lam, Seekings et al., 2005). Outliers (with reservation wages above R500 per day) are excluded.

${ }^{17}$ Data from wave 2B of the Cape Area Panel Study.
} 
economy, it is difficult to set wages are levels that enable public works programmes to be effective poverty-mitigating measures.

\section{Conclusions}

In the North, moves from welfare to workfare have been criticized as a fundamental shift away from the rights of social citizenship. 'Under the new regime, benefits become conditional; obligations are attached to rights. Social citizenship thus changes from status to contract' (Handler, 2004: 2). In the South, calls for workfare represent a demand for the right to work, not the duty to work. The alternative is generally nothing. Insofar as there is a potential alternative, in the form of new social assistance programmes, these are generally unimagined by citizens and dismissed by elites. South Africa is an unusual setting in that both public works programmes and radical welfare reform are not only imaginable, but are actually on the agenda. A basic income grant has been proposed by a government-appointed committee of inquiry, and the government has responded with renewed promises of 'massive' public works programmes.

Both workfare and welfare have the potential to mitigate poverty considerably. Consider the three poor South African households described above. Mrs B would benefit from a basic income grant or employment on a public works programme (assuming that her childcare responsibilies really did not limit her availability for work). Mr and Mrs G's household would benefit handsomely from a basic income grant, given that there are many adults in the household. Mrs G might be too old to work on a road-building PWP herself, but both her son and daughter-in-law are probably candidates for employment. Similarly, Ms K and her sisters would benefit from basic income grants or, given that Ms $\mathrm{K}$ 's sister is unemployed, employment on a PWP.

A basic income grant is universal (and therefore expensive). Employment on public works programmes is selective, in that it benefits only those people who are available for such employment and as many people as there are employment opportunities. Crucially, the distribution of benefits of a PWP depends on wage-setting: is the available budget spent on a smaller number of high-wage jobs, some of which will be taken up by the nonpoor, or on a larger number of low-wage jobs, which will be better targeted?

The total costs of a basic income grant and of a 'massive' public works programme need not be very different. A universal basic income grant, set at just R100 (US\$15) per month per person (excluding people already receiving one or other form of social assistance) would cost an estimated gross R54 billion (between US\$8 and 9 billion) per year (Le Roux, 2002). McCord (2003) calculated that a PWP providing 3.2 million jobs, or 845 million workdays, at R35 (US\$5) per day, would cost between R37 billion and R61 billion per year, depending on administrative costs. This would absorb about 40 percent of the potential workdays of the unemployed in South Africa. Expenditure of about R50 billion per year corresponds to about 3 percent of GDP. 
In at least three respects, however, a basic income grant has advantages over massive public works programmes. First, South Africa's trade unions have insisted that employment 'opportunities' on public works programmes be temporary. If employment was to become more long-lasting, then the unions would push for still higher wages. Secondly, it is unlikely that the state has the capacity to administer public works programmes on anything like this scale. The experience to date of relatively tiny public works programmes suggests that the costs of implementing massive programmes would be far, far higher than McCord suggests. In contrast, the state has considerable experience in delivering social grants. It already delivers ten million grants every month, increasingly making use of computerized banking technologies. Introducing a basic income grant would double the welfare budget and entail between four and five times as many payments per month, but this challenge would be minor compared to that of implementing massive public works programmes.

Thirdly, if appropriately financed, a basic income grant would be better targeted than public works programmes. This is true even if the basic income grant is universal, i.e. rich and poor people alike receive the grant. The most viable proposals for financing a basic income grant have been made by Le Roux (2002), who proposes increasing indirect taxes (i.e. Value Added Tax and 'sin' taxes on tobacco, alcohol and fuel). Increasing indirect taxes means that the net gain to the poor of a R100 per month basic income grant is less than R100. But because the rich spend so much more than the poor, they pay very much more indirect tax. Le Roux calculates that increasing indirect taxes by approximately 50 percent to pay for the basic income grant would result in households in the poorest income decile paying R34 more in tax per month, so that their net gain would be R66 per month. Households in the bottom five deciles enjoy net gains, households in the sixth decile enjoy small net gains, households in the seventh and eighth deciles experience no significant net benefits or losses, but households in the richest two deciles are massive net payers in that they pay much more in tax than they benefit from the (universal) grant. Financed this way, the basic income grant entails a net transfer of about R15 billion (US\$2 billion) or less than 1 percent of GDP from the richest two deciles to the poorest five deciles. Public works programmes could not be financed in the same way, or at least not without very inequitable consequences, since the majority of poor households that did not have members in public work programmes would end up paying in tax without benefiting, thereby getting poorer. High-wage public works programmes would also attract many non-poor, and the administrative costs (entailing 'leakages' of benefits to the non-poor) are much higher than for social grants.

In a setting where trade unions are powerful and are opposed to low-wage or long-lasting public works programmes, and in which the state lacks the capacity to administer public works programmes on a large scale, there are both political and administrative reasons why a basic income grant might be more viable, even if public opinion prefers employment to income support. But the basic income grant has strong opponents also, including fiscal conservatives within the governing party and state, as well as business. The poor are not powerful politically. Even the trade unions might be more ambivalent in their enthusiasm for a basic income grant than they like to admit, especially if it is to be financed out of indirect taxation (Matisonn and Seekings, 2004). Even in a relatively 
favourable context such as South Africa, the choice is still probably not between workfare and welfare, but between either of these and the status quo. In the status quo, workfare and welfare together provide selectively generous support to some poor households, but many other poor households are left out, having to rely on 'informal' welfare arrangements or none at all. 


\begin{tabular}{|c|c|c|c|}
\hline \multicolumn{4}{|c|}{ Appendix: Summary of major players' positions on PWPs and BIG } \\
\hline Player & $\begin{array}{c}\text { Political and } \\
\text { economic power }\end{array}$ & Position on PWPs & Position on BIG \\
\hline $\begin{array}{c}\text { Government/ } \\
\text { ANC/state }\end{array}$ & Strong & $\begin{array}{c}\text { Ideologically favours } \\
\text { workfare. } \\
\text { But does not have the capacity } \\
\text { to implement major PWPs }\end{array}$ & $\begin{array}{c}\text { Has capacity to implement BIG. } \\
\text { But wary of costs of a BIG } \\
\text { programme, and ideologically } \\
\text { opposed to welfare. }\end{array}$ \\
\hline Business & Strong & $\begin{array}{c}\text { Wary of costs of PWPs. } \\
\text { But sympathetic to PWPs. }\end{array}$ & $\begin{array}{c}\text { Wary of costs of BIG. } \\
\text { Ideologically opposed to BIG. }\end{array}$ \\
\hline $\begin{array}{c}\text { Organised } \\
\text { labour }\end{array}$ & Strong & $\begin{array}{c}\text { Supportive of PWPs as long as } \\
\text { wages on PWPs are } \text { not low. }\end{array}$ & $\begin{array}{c}\text { Moderately supportive of BIG, } \\
\text { subject to it being financed out } \\
\text { of income taxes not sales taxes. } \\
\text { Difficult to imagine a BIG. }\end{array}$ \\
\hline Poor & Weak & Favour PWPs. &
\end{tabular}




\section{References}

Altman, Miriam (2003). 'The State of Employment and Unemployment in South Africa'. In John Daniel, Adam Habib and Roger Southall (eds), State of the Nation: South Africa, 2003-04 (Pretoria: Human Sciences Research Council Press).

ANC (1994). The Reconstruction and Development Programme (Johannesburg: African National Congress).

----- (2005). 'Development and Underdevelopment'. Edited version of ANC discussion document, published in South African Labour Bulletin 29 (2): 18-22.

Bhorat, Haroon, and Rashad Cassim (2004). '...' Development Southern Africa 21 (1), March. An edited version was republished as 'How can the South African steam engine become a Ferrari?', South African Labour Buulletin 28 (2) April: 21-26.

Borzutzky, Silvia (2002). Vital Connections: Politics, Social Security and Inequality in Chile (Notre Dame: University of Notre Dame Press).

Bray, Rachel (2003). "Predicting the Social Consequences of Orphanhood in South Africa". CSSR Working Paper no.29 (Cape Town: Centre for Social Science Research, University of Cape Town).

Bryceson, Deborah, and V. Jamal (eds) (1997). Farewell to Farms: De-agrarianisation and Employment in Africa (Aldershot: Ashgate).

Casale, Daniela, Colette Muller and Dorrit Posel (2005). "'Two Million Net New Jobs": A Reconsideration of the Rise in Employment in South Africa, 1995-2003'. DPRU Working Paper no. 05/97 (Cape Town: Development Policy Research Unit, University of Cape Town).

Castles, Francis (1985). The Working Class and Welfare: Reflections on the Political Development of the Welfare State in Australia and New Zealand (Sydney: Allen and Unwin).

Esping-Andersen, Gosta (1990). The Three Worlds of Welfare Capitalism (Princeton: Princeton University Press).

Fridberg, Torben, and Niels Ploug (2000). 'Public Attitudes to Unemployment in Different European Welfare Regimes', in Duncan Gallie and Serge Paugam (eds), Welfare Regimes and the Experience of Unemployment in Europe (Oxford: Oxford University Press), 334-48.

Galasso, Emanuela, and Martin Ravallion (2003). 'Social Protection in a Crisis: Argentina's Plan Jefes y Jefas', World Bank Economic Review 18,3 (2004): 367401.

Gough, Ian, and Geof Wood, with Armando Barrientos, Philippa Bevan, Peter Davis and Graham Room (2004). Insecurity and Welfare Regimes in Asia, Africa and Latin America (Cambridge: Cambridge University Press).

Handler, Joel (2004). Social Citizenship and Workfare in the United States and Western Europe: The Paradox of Inclusion (Cambridge: Cambridge University Press). 
Hirway, Indira, and Piet Terhal (1994). Towards Employment Guarantee in India: Indian and International Experiences in Rural Public Works Programmes (New Delhi: Sage).

Lam, David, Jeremy Seekings et al. (2005). 'The Cape Area Panel Study: An Introduction and User's Guide' (Cape Town: Centre for Social Science Research, University of Cape Town).

Le Roux, Pieter (2002). 'Financing a Universal Income Grant in South Africa'. Social Dynamics 28 (2) (Winter): 98-121.

Leibbrandt, Murray, Haroon Bhorat and Ingrid Woolard (2001), "Understanding Contemporary Household Inequality in South Africa", in Fighting Poverty: Labour Markets and Inequality in South Africa, ed. H.Bhorat, M.Leibbrandt, M.Maziya, S.van der Berg and I.Woolard (Cape Town: University of Cape Town Press).

Malloy, James (1979), The Politics of Social Security in Brazil (Pittsburgh: University of Pittsburgh Press).

Matisonn, H. and J. Seekings (2003). 'The Politics of the Basic Income Grant in South Africa, 1996-2002'. In G. Standing and M. Samson (eds). A Basic Income Grant for South Africa (Cape Town: University of Cape Town Press), 56-76.

McCord, Anna (2003). 'An Overview of the Performance and Potential of Public Works Programmes in South Africa'. CSSR Working Paper no.49 (Cape Town: Centre for Social Science Research, University of Cape Town).

----- (2004). 'Public Works: Policy Expectations and Programme Reality'. CSSR Working Paper no.79 (Cape Town: Centre for Social Science Research, University of Cape Town).

----- and Dirk van Seventer (2004). 'The Economy-Wide Impacts of the Labour Intensification of Infrastructure Expenditure in South Africa'. CSSR Working Paper no.93 (Cape Town: Centre for Social Science Research, University of Cape Town).

Meso-Lago, Carmelo (1978). Social Security in Latin America: Pressure Groups, Stratification and Inequality (Pittsburgh: U. of Pittsburgh Press).

Nattrass, Nicoli (2000). 'The Debate about Unemployment in the 1990s'. Studies in Economics and Econometrics 24 (3): 73-89.

----- (2002). 'AIDS and Human Security in Southern Africa'. Social Dynamics 28 (1), special issue on "AIDS and Society" (Summer): 1-19.

----- (2003). 'The State of the Economy'. In John Daniel, Adam Habib and Roger Southall (eds), State of the Nation: South Africa, 2003-04 (Pretoria: Human Sciences Research Council Press).

----- (2006 forthcoming). 'Trading Off Income and Health: AIDS and the Disability Grant in South Africa'. Journal of Social Policy (January 2006).

----- and Richard Walker (2005). 'Unemployment and Reservation Wages in Working Class Cape Town'. South African Journal of Economics (September). 
Phillips, Sean (2004). 'The Expanded Public Works Programme'. Paper presented at a workshop on "Overcoming underdevelopment in South Africa's second economy" hosted by the UNDP, HSRC and DBSA (28-29 October).

Quisumbing, Agnes R., and Yisehac Yohannes (2005). 'How fair is workfare? Gender, public works and employment in rural Ethiopia'. Policy Research Working Paper no. 3492 (Washington DC: the World Bank).

Ravallion, Martin (1991). 'Reaching the Rural Poor Through Public Employment: Arguments, Evidence and Lessons from South Asia'. World Bank Research Observer 6,2 (July): 153-75.

----- (1999). 'Appraising Workfare'. World Bank Research Observer 14,1 (Feb): 31-48.

Rocha (2001). 'Workfare Programmes in Brazil: An Evaluation of their Performance'. SES Paper no. 13 (Geneva: International Labour Organisation).

Seekings, Jeremy (2000). 'The origins of social citizenship in pre-apartheid South Africa'. South African Journal of Philosophy 19,4 (December): 386-404.

(2002), 'The Broader Importance of Welfare Reform in South Africa', Social Dynamics 28,2 (Winter), special issue on 'Welfare reform in South Africa', 1-38.

----- (2004). 'Trade Unions, Social Policy and Class Compromise in Post-Apartheid South Africa'. Review of African Political Economy no.100: 299-312.

---- (2005a). 'Prospects for Basic Income in Developing Countries: A Comparative Analysis of Welfare Regimes in the South'. CSSR Working Paper no. 104 (Cape Town: Centre for Social Science Research, University of Cape Town).

---- (2005b). "“Visions and Hopes and Views about the Future": The Radical Moment of South African Welfare Reform' in Saul Dubow and Alan Jeeves (eds), Worlds of Possibility: South Africa in the 1940s (Cape Town: Double Storey).

(2005c). 'Social Policy Reform and the Transformation of Markets, States and Communities in Middle- and Low-Income Countries'. Paper presented at the 10th International Karl Polanyi Conference, Istanbul (October).

----- and Nicoli Nattrass (2005). Class, Race and Inequality in South Africa (New Haven: Yale University Press).

-----, Karin Alexander, Tracy Jooste and Isaac Matzner (2004). 'The 2003 Cape Area Study: A User's Guide'. CSSR Working Paper no. 61 (Cape Town: Centre for Social Science Research, University of Cape Town).

-----, with Tracy Jooste, Mirah Langer and Brendan Maughan-Brown (2005). 'Inequality and Diversity in Cape Town: An Introduction and User's Guide to the 2005 Cape Area Study'. CSSR Working Paper no. 124 (Cape Town: Centre for Social Science Research, University of Cape Town).

Streak, Judith, and Carlene van der Westhuizen (2004). 'Fitting the Pieces Together: A Composite View of Government's Strategy to Assist the Unemployed in South Africa, 1994-2004'. Idasa Occasional Paper (Cape Town: Budget Information Service, Institute for Democracy in South Africa). 
Subbarao, Kalanidhi (2001). 'Systemic Shocks and Social Protection: Role and Effectiveness of Public Works Programmes'. Social Protection Discussion Paper no.0302 (Washington DC: the World Bank).

Van Oorschot, Wim. 2004. 'A 1995 Dutch Survey on "Public Opinion on Social Security",. Paper for the ESPAnet Expert Seminar, 'Public Opinion and Social Policy in Europe', Tilburg University (October).

White, Gordon and Roger Goodman (1998), 'Welfare Orientalism and the Search for an East Asian Welfare Model', in Roger Goodman, Gordon White and Huck-ju Kwon (eds), The East Asian Welfare Model.

World Bank (2004). Poverty in Mexico (Washington DC: the World Bank).

----- (2005). Old Age Support in the Twenty-First Century (Washington DC: the World Bank). 